\title{
Professional Competency Gap Analysis Teacher in Professional Development Teacher
}

\author{
$1^{\text {st }}$ Wawan Karsiwan \\ Educational Administration \\ Department \\ STKIP Muhammadiyah Bogor \\ Bogor, Indonesia \\ wawan.karsiwan@stkipm-bogor.ac.id \\ $4^{\text {th }}$ Ana Ratnasari \\ Educational Administration \\ Department \\ STKIP Muhammadiyah Bogor \\ Bogor, Indonesia
}

\author{
$2^{\text {nd }}$ Naufal Ramadian \\ Educational Administration \\ Department \\ STKIP Muhammadiyah Bogor \\ Bogor, Indonesia
}

\author{
$3^{\text {rd }}$ Jasra Putra \\ Educational Administration \\ Department \\ STKIP Muhammadiyah Bogor \\ Bogor, Indonesia
}

\begin{abstract}
This research aims to excavate the professional competency gap of teachers, where the result of the competency gap analysis is the basis for development of the teacher's professional program. Analysis of professional competency gaps of important teachers is done in improving the effectiveness and efficiency of the implementation of teacher's professional development programs. The research approach used is the research of the mix method, where the data is excavated qualitative and quantitative type. The research samples that are the source of information and data in the research are foundation, principals, and teachers. In the collection of data and research information, this data collector tool is used in the form of interview guidelines, selfassessment inventory, and documents related to the competency and performance of the teacher. The analysis of the collected data is done by the quality and quantitative analysis. The result showed, the professional competence of teachers still shows the gap between actual professional competence and expected gap is still quite high in its level of silence. Therefore, ini developing professional improvement program teachers need to refer to the results of the analysis of professional competency gaps of teachers acquired. So that the professional competency development program is expected to be effective and efficient in enhancing the professional competence of teachers.
\end{abstract}

Keywords-Professional Competence, Teacher, Development

\section{INTRODUCTION}

In accordance with the Teacher law's mandate stating that teachers are professional positions. So as a professional position, teachers are required to be able to fulfill the requirements as professional positions. Stated in the law a teacher must have four competencies, namely: personality, social, pedagogic, and professional competence. With competence, it is hoped that the teacher can display his identity as a professional especially in the performance of his profession.

Becoming a professional teacher must have the ability to perform its professional duties, namely: making learning planning, conducting learning, and evaluating learning. Therefore, to become a professional, teachers should always improve their competence. So with its competence, it can improve the quality of learning. With its high competence, it is expected that the teaching and learning process will run well and will encourage higher student learning achievements [1][2].

One of the indicators of the success of teacher competence in carrying out their profession in learning can be seen in the achievement of students gained. The increasing quality of learners should focus on the quality of teaching in the classroom, and more specifically on teachers as keys to improving the performance of its students [3]. The effectiveness of school reform initiatives depends on the quality of teachers and the motivation of teachers to participate in the training and implementing innovations [4].

Therefore it becomes important in implementing a professional improvement program of teachers based on the competency gap analysis that is experienced by teachers as a basis for the professional development of teachers. Many professional development programs seem to still not be able to reduce the competency gaps experienced by teachers. Many professional development programs are conducted based on a policy to down by ignoring the real teacher competency gaps occurring in the learning process. Various professional development programs of teachers are still not able to answer in reducing the teacher's competency gap. One of the efforts to develop the competency of teachers is through the 
continuous Professional Development program which is encouraged through the collective activities of teachers and training [5]. However, some of the studies that have been conducted still show that ongoing professional development programs are still not in accordance with the needs of teachers' competency development [5][6].

Gap analysis is an attempt to dig gaps between actual competencies and competencies that teachers expect in conducting their learning. With the right competency analysis, the competency of teachers will be mapped in need of a competency improvement program. Meanwhile, the Teachers ' competency improvement program is implemented solely based on the needs of the organization has not touched the competency gaps that occur in teachers.

\section{RESEARCH METHODS}

The research method used in this study is a research method of mixed methods with exploratory type design. This is because the data that is excavated is qualitative and quantitative data. The Mix Method is a rich field for the combination of data because with this design, "words, images, and narrative can be used to add meaning to the number"[7]. The design of research Mix Method is a procedure for collecting, analyzing, and "mixing " quantitative and qualitative methods in a single study or a series of studies to understand research problems [8]. The data sources in this study consisted of Yayasan Pendidikan Avicenna Prestasi, principals, and teachers of the first secondary school Avicenna. And to support the excavation of data in this study used several data collection tools in the form of interview guidelines, poll of self-assessment inventory. Data analysis will be conducted with a qualitative and quantitative approach. And to calculate the professional competency gap analysis The teacher is done by testing the difference of two averages of sample groups between actual competencies and competencies that are expected to be achieved by the teacher.

\section{RESULTS}

Professional competence teachers are complications directly related to the implementation of learning activities. Teachers who are professional competencies are expected to improve the learning quality and can further improve student achievement. Based on the deepening of information and data by the interview with the foundation and principal.Obtained information that still needs improvement of teacher competence in conducting the learning. This is because some of the subjects still show less encouraging results. The results of the students' national exam still need improvement.

Meanwhile, through a survey conducted with the selfassessment of inventory competency professional teachers, based on the results of the analysis of professional competency gap teachers obtained results in the form of competency gap of teachers as in the table below.

TABLE I. PROFESSIONAL TEACHER COMPETENCY GAPS

\begin{tabular}{|c|c|c|c|}
\hline INDICATOR & $\begin{array}{c}\text { ACTUAL } \\
\text { COMPETENCIES }\end{array}$ & $\begin{array}{c}\text { EXPECTED } \\
\text { COMPETENCIES }\end{array}$ & $\begin{array}{c}\text { COMPETENCY } \\
\text { GAPS }\end{array}$ \\
\hline $\begin{array}{c}\text { I have mastered the material that } \\
\text { supports the subjects that it can be. }\end{array}$ & 4,27 & 4,87 & 0,60 \\
\hline $\begin{array}{c}\text { I can organize the material structure } \\
\text { to facilitate the delivery of subjects I } \\
\text { can }\end{array}$ & 4,07 & 4,87 & 0,80 \\
\hline $\begin{array}{c}\text { I use various ways of learning to } \\
\text { support the delivery of materials }\end{array}$ & 3,77 & 4,77 & 1,00 \\
\hline $\begin{array}{c}\text { I developed tools to maximize the } \\
\text { delivery of materials according to } \\
\text { the student learning style }\end{array}$ & 3,90 & 4,77 & 0,87 \\
\hline $\begin{array}{c}\text { I follow every development activity } \\
\text { done by the school }\end{array}$ & 4,00 & 4,73 & 0,73 \\
\hline $\begin{array}{c}\text { I apply the training results I have } \\
\text { gained in learning activities }\end{array}$ & 3,87 & 4,60 & 0,73 \\
\hline $\begin{array}{c}\text { I do class action research in } \\
\text { developing learning }\end{array}$ & 2,93 & 4,07 & 1,13 \\
\hline Total Average & $\mathbf{3 , 8 3}$ & $\mathbf{4 , 6 7}$ & $\mathbf{0 , 8 4}$ \\
\hline
\end{tabular}

According to the table above, there is still a professional competency gap of teachers 0.84 . Competency gaps of this amount are obtained through the reduction on the purpose of the teacher's professional competency indicators, namely: (1) mastery of teaching materials; (2) ability to construct material structures; (3) learning methods; (4) learning of media use; (5) development program participation; (6) implementation of development results; and (7) research class action.

In the first indicator, the mastery of the teacher material still shows the competency gap of 0.60 among the current competencies mastered teachers and competencies that are expected to be mastered by teachers. Secondly, the ability of teachers to structure the material, there is still a gap of 0.80 among the actual competencies of teachers with the competencies that teachers should have. Thirdly, the use of learning methods in learning still has a gap of 1.00 among the actual competencies with competencies that are supposed to be owned by the teacher. Fourth, the use of media learning in learning there is a gap of 0.87 among the actual competencies with the competencies that are expected to be strengthened by the teacher. Fifth, the participation of teachers in the competency development program still there is a gap between development programs that have been involved with the supposed to be in the amount of 
0.73. Sixth, implementation of the training results in learning is still there is a gap of 0.73. And, seventh conducting class action research, teachers still have a gap of 1.13 among teachers who have conducted class action research with what the teacher should do.

Based on the analysis of the competency gaps of professionals conducted, it can be seen that teachers are still very rarely doing class action research is the highest gap by the teacher. In this case, the study of the class action as a reflection of the quality improvement of the education service that is supposed to be done by teachers is rarely done by teachers. Furthermore, the teacher's ability to use varied learning methods remains an obstacle in the teacher's professional competence. And successively next to the competencies of learning media use, ability to structure teaching materials, participation in the development and implementation programs, and mastery of materials.

\section{DISCUSSION}

Competence is an important aspect that a professional teacher needs, with competencies he/she is expected to drive to the quality of learning services and better student learning achievement. In Law No. 20 of 2003 on the national education system on points 42 it is stated that educators must have a minimum qualification, certification according to the level of teaching authority, healthy physical and spiritual, and have the ability to realize national educational objectives. And reaffirmed by Law RI number 14 the year 2005 about teachers and lecturers in article 1 that stated teachers are professional educators with the primary task of educating, teaching, guiding, directing, training, assessing and evaluating students in early childhood education of formal education, primary education, and secondary education. Some of the competencies that must be held by the teachers in the Regulation of the Minister of National Education Number 16 the year 2007 about the qualifications and competency standards of teachers, that there are four complete competencies that teachers must have are personality, social, pedagogic and professional competence.

Therefore, it is important a teacher be an effective teacher, in this case. stated that an effective teacher refers to the measure of the success of the teacher in carrying out institutional tasks and other special tasks demanded by the function of his office [9]. The effectiveness of teachers includes the ability to develop learning strategy, good governance of students and classes, and to improve interpersonal relationships, as well as to conduct evaluation and feedback and so forth. An effective teacher is expected to be able to perform its functions as a professional teacher. For that, it becomes important that the teacher can portray herself as a professional teacher as well as an effective teacher.

Competency gap analysis is the main goal of the analysis of development needs which is a strategic process involving the identification of organizational objectives, the collection of competencies and information analysis, determining the gap between the current situation and future needs [10][11][12][13][14]. Need analysis is a useful tool for leaders to design training and development programs well as it focuses on the actual needs of employees and helps explain where, when, how, and what type of training activities are given to the workers [13]. Therefore, based on the results of the analysis of professional competency gaps conducted the implications of a professional competency development program that needs to be done based on the needs of competency priorities with the highest gap level.

Thus, the analysis of the initial condition of the teacher's competence serve as the base-line, and from the initial condition of the competence to the analysis of the needs of the teachers' competency development, and the basis of determining the type of activity that will be done next [15]. Based on the competency gap analysis data, some improvement programs that need to be done are: class action research is the highest gap by the teacher, then the improvement of teacher's ability to use varied learning methods is still a constraint in teacher's professional competence. And successively involved in the use of learning media, the ability to structure teaching materials, participation in the development and implementation programs, and mastery of the materials.

\section{CONCLUSION}

The teacher's professional competence gap analysis is an effort to explore the competency problems that directly relate to the ability of teachers in carrying out their professional assignments in learning. With precise analysis of professional competency gaps, it can determine the effective and efficient professional enhancement programs of teachers. With the improvement of professional competence, teachers are better expected to be encouraged to improve the quality of learning performed by teachers.

\section{REFERENCES}

[1] J. Douglas, R. J. Mcclelland, R. Mcclelland, and J. Davies, "The development of a conceptual model of student satisfaction with their experience in higher education," Qual. Assur. Educ., vol. Vol. 16 No, 2008.

[2] B. Fauth et al., "The effects of teacher competence on student outcomes in elementary science education: The mediating role of teaching quality," Teach. Teach. Educ., vol. 86, p. 102882, 2019.

[3] G. M. Steyn, "Educators â€ $€^{\mathrm{TM}}$ perceptions of continuing professional development for teachers in South Africa: A qualitative study Educators , perceptions of continuing professional development for teachers in South Africa: A qualitative study," no. November 2014, pp. 37-41, 2010.

[4] G. Gorozidis and A. G. Papaioannou, "Teachers ' motivation to participate in training and to implement innovations," vol. 39, pp. 1-11, 2014.

[5] Dedi Kurniady and Aan Komariah, "A Review of continous professional development in school principal carrier," Opcion, 2018.

[6] Andreas Schleicher, International Summit on the Teaching Profession Teaching Excellence through Professional Learning and Policy Reform Lessons From Around The World. Paris: OECD, 2016.

[7] S. N. Hesse-Biber, Mixed Methods Research Merging Theory with Practice. New York: The Guilford Press, 2010.

[8] J. W. Creswell, Research design: Qualitative, quantitative, and mixed methods approaches, vol. 3rd. 2009

[9] A. Sengottuvel, T. Nadu, and T. Nadu, "Teacher Effeectiveness and Professional Competency In School Education," Int. J. Manag., vol. 6502, no. Icam, pp. 181-190, 2015.

[10] J. Carlisle, R. Bhanugopan, and A. Fish, "Training needs of nurses in public hospitals in Australia Review of current 
practices and future," 2011.

[11] S. Denby, "The importance of training needs analysis," Ind. Commer. Train., vol. 42, no. 3, 2010.

[12] J. Shyan and L. Lin, "Journal of Hospitality and Tourism Management Training needs assessment in a hotel using 360 degree feedback to develop competency-based training programs," J. Hosp. Tour. Manag., vol. 20, pp. 61-67, 2013.

[13] A. Khan and M. N. Masrek, "Training needs analysis based on mismatch between the acquired and required levels of collection management skills of academic librarians Article information :", no. December, 2017.

[14] R. R. G. Priyadarshini and D. Dave, "Competency-based Training Needs Assessment Model," 2012.

[15] S. Anif, "Pengembangan Model Peningkatan Kompetensi Profesional Guru Biologi Berbasis Continuos Professional Development (CPD) Di Surakarta," Univ. Res. Collaquium, pp. 271-283, 2015 